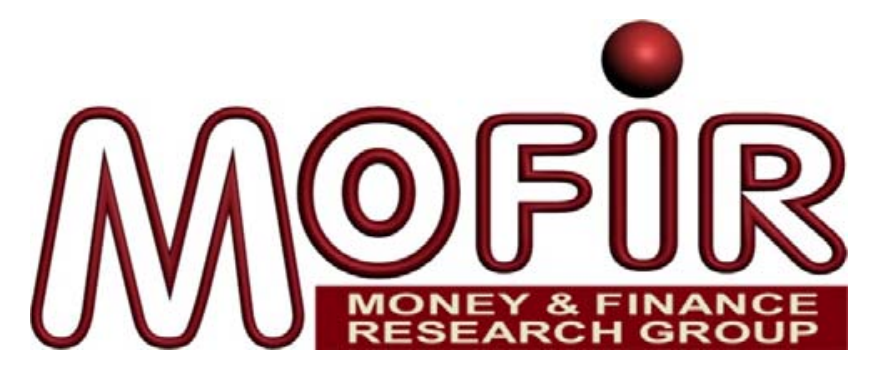

\title{
EXCHANGE RATE, EXTERNAL ORIENTATION OF FIRMS AND WAGE ADJ USTMENT
}

\author{
FRANCESCO NUCCI \\ Sapienza, Università di Roma \\ AlBeRTO FRANCO POZZOLO \\ Università degli Studi del Molise
}

MoFiR working paper $\mathrm{n}^{\circ} 70$

May 2012 


\title{
Exchange Rate, External Orientation of Firms and Wage Adjustment
}

\author{
Francesco Nucci \\ Sapienza, Universita' di Roma \\ Alberto Franco Pozzolo \\ Universita' del Molise, Centro d'Agliano, MoFiR and CASMEF
}

May 19, 2012

\begin{abstract}
We estimate the effect of exchange rate movements on firm-level wages, using a representative panel of manufacturing firms. We show that the direction and size of wage adjustment is shaped by the international exposure of each firm on both the sale and cost side of the balance sheet, similar to the response of employment documented in Nucci and Pozzolo (2010). Through the revenue side, wages tend to rise after a currency depreciation and the effect is more pronounced the higher is the firm's exposure to sales from exports. Through the expenditure side, a depreciation induces a cut in the firm's wages, and the effect is larger the higher is the incidence of imported inputs in total production costs. For a given degree of external orientation, both these effects are larger for firms with a lower market power. Moreover, we document that the effect of exchange rates on wages is shaped by (i) the extent of sectoral import penetration in the domestic market; (ii) the proportion of newly hired workers in each firm in a given year; and (iii) the composition of the firm's workforce by occupational category. JEL classifications: E24; F16; F31.

Keywords: Exchange Rate; Firms' Foreign Exposure; Wages.
\end{abstract}




\section{Introduction}

A considerable body of empirical literature in international economics uncovers non-negligible effects of exchange rate movements on the real economy. For example, Campa and Goldberg (1999; hereafter, CG) and Nucci and Pozzolo (2001; hereafter, NP) show that currency swings significantly affect firm's investment, and NP (2010) and Goldberg and Tracy (2000) find similar effects on employment and hours worked. ${ }^{1}$ From a theoretical perspective, the typical channel through which exchange rates can affect firms' choices is through changes in profitability. A currency depreciation, for example, causes an increase of the costs of imported inputs for production, on one side, and an increase in foreign and domestic revenues on the other side. The overall impact is therefore expected to vary considerably across producers in light of the heterogeneous international orientation on both the export and imported inputs side of each individual firm (see Bernard et al, 2007).

A parallel strand of empirical literature has studied the consequences of exchange rate movements on the earnings of workers, but without reaching a definitive conclusion. On the one hand, a group of contributions, focusing on aggregate data at the industry level, uncovers a significant wage responsiveness to exchange rate oscillations. In particular, Revenga (1992) shows that changes in import prices induced by exchange rate swings do affect real wage in U.S. manufacturing, Goldberg and Tracy (2000), using data disaggregated by states and by industries, report statistically significant estimates of the earnings elasticities with respect to exchange rate, also providing evidence of a pattern of regional differences in their values, and CG (2001) document a significant incidence of exchange rates on wages, that is shown to vary across industries depending on their trade orientation and competitive structure. On the contrary, Goldberg and Tracy (2003), using information on individual workers characteristics such as educational attainment and experience, find that the overall wage effect

\footnotetext{
${ }^{1}$ The latter finding contrasts with previous evidence by CG (2001) of a weak employment response to exchange rates coupled with a significant impact on real wages; differently from CG (2001) and most other studies in this area of literature, NP (2010) use firm- rather than industry-level information and provide arguments for why the level of disaggregation of the data may affect the estimated impact on employment to a considerable extent.
} 
of currency movements is in fact modest, although it can be sizeable for specific groups of workers.

In this paper we contribute to the literature on the effect of exchange rate fluctuations on real wages relying on microeconomic data from a high quality sample of Italian firms, thus complementing the NP's (2010) analysis along a parallel dimension. Information on individual workers, as in Goldberg and Tracy (2003), definitely provides an important perspective, as it allows to appraise which type of workers experience the largest wage adjustment (if any) after an exchange rate shock. ${ }^{2}$ We argue, however, that individual firm characteristics are of particular relevance in shaping the implications for wages of exchange rate fluctuations. In particular, because of the large heterogeneity across firms along several dimensions, even within narrowly defined industries, the firm-specific effects of exchange rate on wages can be to some extent washed out in the aggregation process. This paper therefore analyzes if the estimated wage response to an exchange rate shock varies across firms in association with the response of firm profitability.

In frictionless and competitive labor markets, the change in profitability resulting from an exchange rate swing is not expected to yield any firm-specific effect on the wages of similar workers, as each firm is a wage-taker that faces an infinitely elastic supply of labor. Any shift in the marginal revenue product of labor induced by a currency shock generates firm-level effects on employment, but not on wages. However, this contrasts with the well-established empirical finding that firm profitability does affect its wages, even after controlling for differences in the characteristics of the workers (see e.g., Nickell and Wadhwani, 1990, Abowd and Lemieux, 1993, and Arai, 2003). Indeed, a variety of theoretical models depart from the simplest auction model of the labor market and yield the prediction that workers are paid a wage that does depend on the profits and the financial conditions of their employer. ${ }^{3}$

\footnotetext{
${ }^{2} \mathrm{~A}$ further notable advantage of individual data is that they allow to appraise the role of exchange rate on the wage of workers that decide or are forced to change their job (see Kletzer, 2000 and Goldberg and Tracy, 2003).

${ }^{3}$ As elucidated by Blanchflower et al. (1996) and Hildreth and Oswald (1997), for example, an important class of models feature a bargaining framework where rent-sharing occurs between the firm and its employees, and this establishes a positive link at the firm level between profitability and pay. Alternatively, a competitive model with temporary informational and search-related frictions implies that the individual firm faces an upward-sloping labor supply curve, so that a shock to profitability, induced for example by an exchange rate shock, feeds through into the wage rate, not just into employment. Models where labor contracts have elements of risk-sharing are also conducive to a positive response of the firm wage rate to profits, whose size
} 
Thus, the combined evidence that the effects of currency swings on profitability and labor demand are heterogeneous across firms, depending on their international exposure, and that differences in profitability across firms are conducive to differences in wages of similar workers calls for an investigation on firm-level data of the exchange rate-wages link. In particular, we are able to estimate a specific, time-varying responsiveness of the (average) wage to exchange rate for each individual firm and in doing so we explicitly allow for a number of transmission channels of the currency shock to the wage rate whose relevance varies from firm to firm.

To provide the motivation for the empirical analysis, following NP (2001; 2010) and CG $(1999 ; 2001)$ we refer to a theoretical model that pins down a number of mechanisms through which exchange rate changes may influence the wages set by the firm. The prediction that exchange rates affect not only a firm's labor demand but also the level of its wages is obtained by assuming that in the short run labor is imperfectly mobile, due to search and informational frictions that make each employer facing an upward-sloping labor supply curve, rather than a horizontal one at the economy-wide wage, as if the labor market was perfectly competitive. In this setting, a currency depreciation causes a surge in equilibrium profitability and in the wage level, through the revenue side of the income account, and the effect is stronger the higher is the incidence of a firm's sales in the foreign markets. Conversely, through the cost side, a depreciation causes a reduction of profits and wages, and the effect in turn is stronger the more a firm relies on imported intermediate inputs. Another prediction of the theoretical model, also testable with our data, is that, for a given level of firm's external orientation, the degree of wage sensitivity to exchange rate is influenced by the market power of the firm. In particular, the impact on wages can be shown to be more pronounced the lower is the firm's pricing power in its destination markets (see CG, 2001).

The empirical analysis soundly supports the predictions of the theoretical framework. An exchange rate devaluation causes an increase in wages that is stronger the higher is the share of revenues from exports and the lower is the incidence of imported inputs, and such effects are magnified the lower is the firm's market power in the destination markets. We also investigate the empirical relevance of a number of additional features that shape the responsiveness of firm level wages to exchange rate fluctuations. First, we study the effect of the competitive pressure exerted by foreign producers in the firm's domestic market. In particular, following NP (2010), we investigate whether differences across industries in the depends on the degree of relative risk aversion of the workers and the firm. 
degree of import penetration are conducive to diverging patterns in the response of wages to currency shocks. In doing so, we combine firm-level information on the exposure of the firm's sales on the domestic product markets with data on import penetration in the industry to which the firm belongs. We find that a currency depreciation, by reducing the competitiveness of importers in the domestic market, increases the profitability of domestic firms and thereby their wages, through the domestic revenue channel. This effect is found to be stronger the higher is the extent of import penetration and the larger is the degree of firm's orientation to the domestic product market. Second, we analyze the role of the share of newly hired workers in shaping the impact of exchange rate movements on the wages set by the firm. In particular, we consider the hiring rate for each firm and test whether two firms with a different percentage of newly hired employees in a given year, but identical along all other dimensions (e.g., their international exposure), show a different sensitivity of their wages to exchange rate shocks. We find that this sensitivity is indeed larger for firms with a higher hiring rate through both the revenue and the cost sides. Arguably, this result complements the one obtained on employees data by Goldberg and Tracy (2003), who detect a significant effect of exchange rate swings on the size of the adjustment in wages associated with a transition from one job to another. Finally, whilst our data do not allow to control for individual worker characteristics such as the skill level, nonetheless we exploit the timevarying information on the composition of each firm's workforce to examine whether the wage responsiveness to exchange rate through both the revenue and cost side varies across firms with different incidence of white- versus blue-collar workers. It turns out that it does, as the wage responsiveness is higher, ceteris paribus, for firms with a higher proportion of white-collar employees.

We organize the remainder of the paper as follows: Section 2 presents the theoretical relationships that guide our empirical analysis and provide motivation for it. Section 3 describes the data, the empirical specification and the estimation methodology. In Section 4 we report the empirical results with regard to the baseline specification as well as to additional features characterizing the wage responsiveness to exchange rate swings. Section 5 concludes. 


\section{Theoretical framework}

\subsection{The Model}

In this section we present a simple model of the labor market that allows us to illustrate the mechanisms through which exchange rate swings can induce equilibrium wage adjustment. Following CG (1999; 2001) and NP (2001; 2010), we consider the optimal conditions for profit maximization of a firm operating in an imperfectly competitive market. The firm's problem is defined as:

$$
\max _{q, q^{*}, z, z^{*}, L} \pi\left(q, q^{*}, z, z^{*}, L, e\right)=p(q, e) q+\frac{p^{*}\left(q^{*}, e\right) q^{*}}{e}-z s-\frac{z^{*} s^{*}(e)}{e}-w L,
$$

subject to the technology constraint:

$$
q+q^{*}=Q=F\left(L, z, z^{*}\right)
$$

where $q$ and $q^{*}$ are the volumes of production for the domestic and the foreign markets, respectively, and the inverse demand functions, $p(q, e)$ and $p^{*}\left(q^{*}, e\right)$, have been substituted into the profit function; $L$ is employment and $z$ and $z^{*}$ are the levels of domestically produced and imported non-labor inputs, respectively; $w$ is the wage and $s$ and $s^{*}$ are the prices of the domestically produced and the imported inputs, respectively, expressed in local currency; $e$ is the exchange rate, quoted as the number of foreign currency units per domestic currency unit (i.e., an increase of $e$ is therefore a currency appreciation). The first order conditions with respect to $q$ and $q^{*}$ for the solution of the constrained maximization problem (1) are:

$$
\begin{aligned}
\frac{\partial p(q, e)}{\partial q} q+p-\lambda & =0 \\
\frac{\partial p^{*}\left(q^{*}, e\right)}{\partial q^{*}} \frac{q^{*}}{e}+\frac{p^{*}}{e}-\lambda & =0 .
\end{aligned}
$$

where $\lambda$ is the Lagrange multiplier for the technology constraint. By defining $\eta$ and $\eta^{*}$ as the price elasticities of demand in, respectively, the domestic and the foreign product market, from Eqs. (2) and (3) we obtain the following relationship linking prices and demand elasticities in the home and foreign markets:

$$
\lambda=p\left(1+\frac{1}{\eta}\right)=\frac{p^{*}}{e}\left(1+\frac{1}{\eta^{*}}\right) .
$$


Similarly, the first order conditions for profit maximization with respect to $z, z^{*}$ and $L$ are:

$$
\begin{aligned}
-s+\lambda \frac{\partial F\left(L, z, z^{*}\right)}{\partial z} & =0 \\
-\frac{s^{*}(e)}{e}+\lambda \frac{\partial F\left(L, z, z^{*}\right)}{\partial z^{*}} & =0, \\
-w+\lambda \frac{\partial F\left(L, z, z^{*}\right)}{\partial L} & =0 .
\end{aligned}
$$

By combining Eq. (4) with Eqs. (5)-(7), the following equilibrium conditions are derived, equating the marginal revenue product of each input to its marginal cost:

$$
\begin{aligned}
& \frac{\partial F\left(L, z, z^{*}\right)}{\partial z}=\frac{s}{p\left(1+\frac{1}{\eta}\right)}, \\
& \frac{\partial F\left(L, z, z^{*}\right)}{\partial z^{*}}=\frac{s^{*}(e)}{p^{*}\left(1+\frac{1}{\eta^{*}}\right)} \\
& \frac{\partial F\left(L, z, z^{*}\right)}{\partial L}=\frac{w}{p\left(1+\frac{1}{\eta}\right)} .
\end{aligned}
$$

If we assume that technology, $F(\cdot)$, is described by a constant return to scale production function, we can apply Euler's theorem and express total output as follows:

$$
Q=F\left(L, z, z^{*}\right)=\frac{\partial F\left(L, z, z^{*}\right)}{\partial L} L+\frac{\partial F\left(L, z, z^{*}\right)}{\partial z} z+\frac{\partial F\left(L, z, z^{*}\right)}{\partial z^{*}} z^{*} .
$$

By defining $\frac{1}{\mu}=\left(1+\frac{1}{\eta}\right)$ and $\frac{1}{\mu^{*}}=\left(1+\frac{1}{\eta^{*}}\right)$ as the reciprocals of the mark-up ratios set, respectively, in the domestic and foreign product markets, and substituting Eqs. (8)-(10) into Eq. (11), simple algebraic manipulations yield the following equilibrium condition (see CG, 2001 and NP, 2010):

$$
w L=\frac{p q}{\mu}+\frac{p^{*} q^{*}}{e \mu^{*}}-\left(s z+\frac{s^{*} z^{*}}{e}\right) .
$$

The above expression characterizes firm's optimal labor demand in the absence of adjustment costs. Applying the logarithmic transformation and denoting $\widetilde{L}$ as the optimal demand in the absence of adjustment costs, we obtain:

$$
\ln w=\ln \left[\frac{p q}{\mu}+\frac{p^{*} q^{*}}{e \mu^{*}}-\left(s z+\frac{s^{*} z^{*}}{e}\right)\right]-\ln \widetilde{L} .
$$


To allow for the presence of adjustment costs in hiring and firing workers, we assume the following partial adjustment equation for labor demand:

$$
\ln L_{t}=\varphi \ln L_{t-1}+(1-\varphi) \ln \widetilde{L}_{t}
$$

that postulates that the labor demand in period $t$ depends on the level of employment at time $t-1$, and on the optimal level of employment at time $t$ in the absence of adjustment costs, $\ln \widetilde{L}_{t}$, where $\varphi$ is the parameter governing the speed of adjustment to the frictionless equilibrium (NP, 2010).

Combining Eqs. (13) and (14) and introducing the time subscripts where appropriate yield the following expression

$$
\ln w_{t}=\ln \left[\frac{p_{t} q_{t}}{\mu_{t}}+\frac{p_{t}^{*} q_{t}^{*}}{e_{t} \mu_{t}^{*}}-\left(s_{t} z_{t}+\frac{s_{t}^{*} z_{t}^{*}}{e_{t}}\right)\right]-\frac{1}{1-\varphi}\left(\ln L_{t}-\varphi \ln L_{t-1}\right)
$$

The equation above implies that, if the firm was a wage-taker and faced an infinitely elastic supply of labor at the economy-wide prevailing wage level, an exchange rate shock would yield a shift in profitability and labor demand, which would impact on the firm's equilibrium employment but leave the wage rate unaltered. Since this contrasts with the well-established evidence that firm profitability is a relevant determinant of workers pay, even when controlling for their observable differences, we depart from the assumption of a perfectly competitive labor market and consider one of the several frameworks in which firm wages and profits exhibit comovements. In particular, we consider a modified competitive model of the labor market in which the labor supply curve slopes upward. This may arise from temporary frictions resulting from search and mobility costs, informational problems or heterogeneous worker preferences as suggested for example by Blanchflower et al. (1996) and Hildreth and Oswald (1997). ${ }^{4}$

To characterize the equilibrium wage we therefore assume that each firm faces the following labor supply curve:

\footnotetext{
${ }^{4}$ Albeit implicitly, the same hypothesis on the labor market is adopted by CG (2001), where wages are allowed to be different across industries in light of a number of sector-specific characteristics.
} 


$$
\ln L_{t}=a_{0}+a_{1} \ln w_{t}
$$

By equating labor demand (Eq. 15) and labor supply (Eq. 16), simple manipulations yield

$$
\ln w_{t}=A(1-\varphi) \ln \left[\frac{p\left(q_{t}, e_{t}\right) q_{t}}{\mu}+\frac{p^{*}\left(q_{t}^{*}, e_{t}\right) q_{t}^{*}}{e_{t} \mu^{*}}-\left(s_{t} z_{t}+\frac{s^{*}\left(e_{t}\right) z_{t}^{*}}{e_{t}}\right)\right]+A \varphi \ln L_{t-1}-a_{0} A
$$

where $A=\frac{1}{1-\varphi+a_{1}} \geq 0$. Differentiating the above equation with respect to the exchange rate, it is possible to obtain the following expression for the elasticity of wages, $w$, with respect to the exchange rate, $e$ :

$$
\frac{d \ln w_{t}}{d \ln e_{t}}=\frac{1}{\bar{\mu}} \beta\left[-\chi\left(1-\eta_{p^{*}, e}\right)+(1-\chi) \eta_{p, e}+\alpha\left(1-\eta_{s^{*}, e}\right)\right] A(1-\varphi),
$$

where $\chi \in[0,1]$ is the share of sales in foreign markets over total sales ; $\alpha \in[0,1]$ is the share of production costs for imported inputs in total costs; $\eta_{p, e} \in[-1,0]$ and $\eta_{p^{*}, e} \in[0,1]$ are the elasticities of, respectively, domestic and foreign prices with respect to the exchange rate (i.e., the pass-through elasticities); $\eta_{s^{*}, e} \in[0,1]$ is the elasticity of foreign input prices with respect to the exchange rate; and $\beta$ is the share of labor costs over total revenues. In deriving the above expression we have assumed for simplicity that there is no distinction between the mark-up set in the domestic market, $\mu$, and in the foreign product markets, $\mu^{*}$. In both cases we have used $\bar{\mu}$, which can be interpreted as the average value of the destination-specific mark-up ratios. Moreover, we have used the fact that, under constant returns to scale, total revenues can be expressed as the product of production costs (the wage bill plus intermediate input expenditure) and the mark-up ratio, $\bar{\mu}$.

Eq. (18) represents a useful theoretical background for our empirical analysis, providing a variety of testable implications. The following section discusses more in detail the different channels, explicitly identified in our theoretical model, through which exchange rate movements affect the equilibrium outcome for the firm wages. 


\subsection{The Channels of Transmission of the Currency Swings to Wages}

Eq. (18) predicts that exchange rate swings affect firm level wages. If we focus on the revenue side of the firm's balance sheet, a currency depreciation (a reduction of $e_{t}$ ) has a positive effect on the firm's marginal revenue product of labor and thereby on the equilibrium wage, as is shown by the sum of the first two terms inside brackets in Eq. (18), $-\chi\left(1-\eta_{p^{*}, e}\right)+(1-\chi) \eta_{p, e}$, which is non-positive. In particular, a depreciation is predicted to exert a positive effect on wages along both the foreign and domestic sales channels. On the export side, the positive effect on wages of an exchange rate depreciation is larger the higher is the share of foreign sales in total sales, $\chi$, i.e. the more a firm is exposed to foreign markets through the export of its products. On the revenue side as a whole, i.e. including both domestic and foreign sales, the positive effect on wages of a currency depreciation is also amplified as the export share of sales, $\chi$, becomes larger, but this prediction holds true only if the following condition is met: $\left|\eta_{p, e}\right|+\eta_{p^{*}, e}<1$, i.e. if the sum of the exchange rate pass-through elasticities (their absolute value) is less than one (NP, 2010). By contrast, through the cost side of the balance sheet, a currency depreciation negatively affects the marginal revenue product of labor and thereby wages, as implied by the the non-negative term $\alpha\left(1-\eta_{s^{*}, e}\right)$ inside brackets in Eq. (18). Again, the extent of these adjustments depends on the external dependence of the firm on foreign inputs. This is captured in Eq. (18) by $\alpha$, the share of expenditure for imported inputs in total costs: the larger is this share, the more pronounced are the negative implications for wages of a depreciation through this channel of exposure (see CG, 1999; 2001 and NP 2001; 2010).

The theoretical framework illustrated in the previous section highlights other important features that shape the response of wages to exchange rate swings. First, the degree of firm's market power, as measured by the firm's mark-up ratio, $\bar{\mu}$, does enter Eq. (18), with the prediction that, everything else being identical for two hypothetical firms (e.g., the type of foreign exposure and the pass-through elasticities), the one with a lower degree of pricing power exhibits a more sizeable elasticity of wages to exchange rate (in absolute value). Indeed, firms with a lower market power tend to be less capable of absorbing currency shocks, so that the impact on wages is relatively more pronounced. To see this, recall that an exchange rate depreciation (e.g. a decrease of $e$ ) drives down the export price in the foreign currency by an amount that depends on the pass-through elasticity, $\eta_{p^{*}, e}$. This price 
decline therefore yields an increase of foreign demand, $q^{*}$ - and thereby of profitability and wages - which is larger the higher is the price elasticity of foreign demand, $\eta^{*}$. Given the negative relationship between the firm's mark-up ratio and the price elasticity of demand, the sensitivity of wage to currency swings is indeed magnified when the firm's market power is relatively low.

Another prediction of the model (again see Eq. 18) is that the exchange rate pass-through elasticities contribute to shape the adjustment of wage in response to currency shocks. The exchange rate elasticity of the prices set by the firm in the currency of the market of destination, $\eta_{p^{*}, e}$, ranges from zero (no pass-through) to one (complete pass-through). From Eq. (18) we note that, for a given level of external orientation on the export side, $\chi$, the smaller is the (absolute value of the) elasticity of exchange rate pass-through to foreign prices, $\eta_{p^{*}, e}$, the larger is the wage response to a shift in $e_{t}$. Indeed, many contributions show that this exchange rate pass-through elasticity does depend on market structure and in particular on the extent to which firms' products are differentiated and the substitution among different variants is large (Yang, 1997). These studies, that include Dornbusch (1987) and Knetter (1993), show that the pass-through tends to be low if the degree of competition in the foreign markets is high. Therefore, in the limiting case of a perfectly competitive foreign destination market, the firm is a price taker, the pass-through elasticity is zero, and the effect of a depreciation on profits and wages is magnified. This additional channel clearly reinforces the previous conclusion that the lower is the firm's pricing power, the higher is the exchange rate sensitivity of profitability and thereby wages.

If we focus on firm's competition in the domestic market, we have already established that a currency depreciation, by making foreign products more expensive, rises the competitiveness of domestic firms in the home market, thus increasing their sales, their profitability as well as their wages. Eq. (18) predicts that also the exchange rate pass-through elasticity of firm's prices in the domestic market, $\eta_{p, e}$, plays an important role in shaping this effect. The value of this domestic pass-through elasticity ranges from minus one (complete pass-through) to zero (no pass-through), and again it depends on market structure. Specifically, the elasticity is a decreasing function of the firm's monopoly power in the home market (in absolute value). In the limiting case of a perfectly competitive domestic destination market, where the domestic firm is a price taker, a currency appreciation forces it to a one-for-one price cut (a pass-through elasticity equal to minus one). Thus, a currency appreciation lowers the 
value of domestic sales, profitability and wages, and the lower is the firm's market power, the larger is this decline. The intuition is that the higher the competitive pressure exerted by foreign producers, the more responsive are domestic sales, profitability and wages in the aftermath of a currency shift. Indeed, the domestic pass-through elasticity reflects the degree of this competitive pressure from foreign producers, and is often assumed to be proportional to the degree of import penetration in the domestic market (see e.g. Dornsbusch, 1987 and CG, 2001).

Market structure also shapes the effects of exchange rate fluctuations through the cost side of the balance sheet. The increase in wages caused by an exchange rate appreciation through a reduction in the expenditure for imported inputs depends on the extent of competition in the market for intermediate inputs. From Eq. (18), it can be seen that the effect of exchange rate swings on wages is larger the smaller the pass-through elasticity of foreign input prices to the exchange rate, $\eta_{s^{*}, e}$, that ranges from zero (no pass-through) to one (complete pass-through).

As discussed above, the theoretical framework of Section 2.1 allows us to uncover a number of testable implications on the transmission of exchange rate swings to wages. These theoretical predictions, summarized by Eq. (18), lend themselves to the empirical scrutiny, to which we now turn. In doing so, we first present the firm-level panel data that we use in our analysis.

\section{The Data and the Regression Specification}

\subsection{The Data}

The microeconomic data used in the empirical investigation are the the same as those of NP (2010). They are drawn from two different statistical sources. The first one is the Bank of Italy's Survey of Investment in Italian Manufacturing (SIM), that is carried out at the beginning of every year since 1984 on a representative sample of over 1,000 firms, stratified by industry, size and location. These data are of extremely high quality, thanks also to the professional expertise of the interviewers, who are officials of the Bank of Italy establishing long-term relationships with the firms' managers. Only medium-large firms, defined as those with more than 50 employees were included in the Survey during the sample period that we 
analyze. We used SIM to gather firm-level information on total revenues and revenues from exporting, employment and hours worked.

The second source of firm-level data is the Company Accounts Data Service reports, a database maintained by a consortium among the Bank of Italy and a pool of commercial banks, collecting information from balance sheets and income statements of a sample of about 40,000 Italian firms. The detailed information from the annual accounts are reclassified to ensure comparability across firms. From this database we gather firm-level information on the wage bill, expenditure on intermediate inputs, value added and total sales. Data from these two sources are merged to construct an unbalanced panel of slightly fewer than 2,400 firms. As in NP (2010), the data used for estimation covers the period 1984-1998. During these 15 years before the introduction of the euro, the Italian currency Lira experienced pronounced swings. Coupled with the high degree of international exposure of Italian firms on both the revenue and the cost side, this provides an ideal setting for our empirical analysis.

We compute the average wage at the firm level as the total wage bill divided by the average number of employees within each year (average wage per employee) or by the total hours worked (average wage per hour worked). To obtain measures of labor compensation in real terms, we deflate them using the GDP deflator. We also have information at the firm level on the number of hires and separations in each year, as well as a breakdown of the number of employees between blue- and white-collars.

The empirical counterpart of the two key variables on the firm's international exposure, $\chi$ and $\alpha$, are calculated at the firm level for each year. The export share of sales of firm $i$ in year $t, \chi_{i t}$, is directly provided by SIM. To derive the share of imported inputs in total input purchases of firm $i$ in year $t, \alpha_{i t}$, we had instead to integrate our firm-level data from the two statistical sources described above with additional information from the 44-industry inputoutput table of 1992 for the Italian economy, since this information is not directly available. As in NP (2001 and 2010), we extracted for each industry $j$ the values of both imported intermediate inputs and total intermediate inputs (domestically produced and imported). Then, by using time series information on import demand and production for each industry, we updated backward and forward the values of input purchases from the input-output table that refer to one year only. Last, we computed the share of costs on imported inputs in total input purchases as $\alpha_{i t}=\frac{\left(\frac{I M_{j t}}{T E_{j t}}\right) T E_{i t}}{T E_{i t}+L C_{i t}}$, where $I M_{j t}$ is the value of intermediate inputs imported 
by industry $j$ (the industry to which firm $i$ belongs), $T E_{i t}$ and $T E_{j t}$ are the values of total expenditure for intermediate inputs of, respectively, firm $i$ and industry $j$, and $L C_{i t}$ is labor costs of firm $i$.

Following the approach developed by Domowitz et al. (1986), we computed a time-varying measure of each firm's market power as the ratio of the firm's value added net of labor compensation to the value of firm's total production. Ideally, we would use distinct destinationspecific mark-up ratios, for example in the home and the foreign markets. Since our data do not allow to derive them, we construct a firm's average measure of market power for each year.

The exchange rates used in the empirical analysis are the permanent components of the export and import real effective exchange rates of the Italian lira constructed by considering 24 different bilateral exchange rates, based on producer price indexes (see Banca d'Italia, 1998). The permanent component has been derived applying the Beveridge and Nelson (1981) procedure that decomposes a non-stationary series into its permanent and transitory components (see NP, 2010 for details). Figure 1 shows the time profile of the monthly data on import and export real exchange rates in the period analyzed (with an increase of the exchange rates amounting to a real appreciation). While they exhibit a very similar pattern, some differences emerge in the mid-eighties and at the beginning of the nineties.

\subsection{The Econometric Specification}

To assess empirically the wage response to exchange rate fluctuations we rely on a baseline equation which has the following specification:

$$
\begin{aligned}
\Delta w_{i t}=\beta_{0}+\beta_{1} \chi_{i t-1} \Delta \text { peer }_{t} & +\beta_{2} \alpha_{i t-1} \Delta \text { pmer }_{t}+\beta_{3} \chi_{i t-1}+\beta_{4} \alpha_{i t-1}+ \\
& +\beta_{5} \Delta s_{i t-1}+\beta_{6} M K U P_{i t-1}+\beta_{7} \Delta l_{i t-1}+b^{\prime} Z_{i t}+\lambda_{i}+u_{i t}
\end{aligned}
$$

where lower-case letters denote the logarithmic transformation of the variable. $W_{i t}$ is the average wage in real terms paid by firm $i$ at time $t$ (we alternatively use the wage per employee and the wage per hour); $\chi_{i t-1}$ is the share of sales in foreign markets over total sales at time $t-1 ; \alpha_{i t-1}$ is the share of production costs for imported inputs in total costs; 
$P E E R_{t}$ and $P M E R_{t}$ are the permanent components of, respectively, export and import real effective exchange rates, defined so that an increase in the exchange rate is an appreciation; $M K U P_{i t}$ is an index of firms' market power; $L_{i t}$ is the amount of labor input (according to the definition of the real wage adopted, we alternatively measure it as the number of employees and the number of total hours); $S_{i t}$ is the value of real sales; $Z_{i t}$ is a vector of dummy variables controlling for the different years, industries, sizes and geographic locations in which each firm operates. Finally, the specification controls for individual firm latent heterogeneity including firm-level fixed effects, $\lambda_{i} ; u_{i t}$ are the disturbance terms, for which we assume that $E\left(u_{i t}\right)=E\left(u_{i t} u_{i s}\right)=0$, for all $t \neq s$. The empirical specification is in first-differences in light of the non-stationarity of the exchange rate time series.

The dynamic Eq. (19) is a reduced form, but it is straightforward to see it as the empirical counterpart of Eq. (18). It therefore allows us to directly test the implications of the theoretical model. The key variables for characterizing the wage adjustment in response to currency swings are (i) $\chi_{i t-1} \cdot \Delta$ peer $_{t}$, the interaction term of the export share of sales lagged by one period with the export exchange rate variation; and (ii) $\alpha_{i t-1} \cdot \Delta p m e r_{t}$, the interaction term of the lagged share of expenditure for imported inputs in total purchases with the import exchange rate variation. The advantage of this approach using interaction terms is that it allows the estimated sensitivity of wages to currency movements to vary across firms and over time, depending on the evolving external orientation of each specific firm on both the revenue and cost side (see CG, 2001 and NP, 2010). In other words, the empirical framework of Eq. (19) allows us to estimate a time-varying and firm-specific response of firms' labor compensation to exchange rate oscillations, distinguishing between the export revenues and the imported input cost channels. Of course, the export share of sales and the share of imported inputs are also inserted in the specification as single regressors in isolation.

The lagged value of changes in the firms' real sales is included to control for demand conditions, and the lagged value of the mark-up ratio to control for any effect of marginal profitability on wages that is independent of exchange rate oscillations. Consistent with the theoretical set-up (see Eq. 18), the specification includes the lagged value of change in employment (or hours) to control for the adjustment lags that typically characterizes the labor market.

As in NP (2001 and 2010), we use the generalized method of moments (GMM) estimator for dynamic panel data models, which was shown to be efficient within the class of instru- 
mental variable estimators (Arellano and Bond, 1991). Indeed, since in Eq. (19) the lagged values of the mark-up ratio and of change in employment (hours) and sales are likely to be correlated with the firm-specific fixed effects, $\lambda_{i}$, the endogeneity of these regressors might cause inconsistency of the parameters estimated with standard panel methods. The GMM estimator ensures their consistency. Specifically, following Arellano and Bover (1995), we rely on the system GMM panel estimator, which augments the Arellano and Bond (1991) estimator by building a system of two equations: the original equation and a transformed one, where a variety of instruments in levels can also be used. Under this more novel approach, with the further assumption that first differencing the instrumenting variables in the original equation makes them uncorrelated with fixed effects, it is then possible to exploit an even larger number of orthogonality conditions than before, by resorting to a larger instrument set. In the estimation we utilize as GMM-type of instruments the lagged values of real sales, employment (or hours) and of the mark-up dated period $t-2$ and earlier. The validity of our specification is ascertained by conducting (i) the Hansen test of over-identifying restrictions, which seeks to verify the orthogonality between instrumental variables and the disturbance terms and (ii) the Arellano-Bond test for second-order serial correlation of residuals of the transformed equation. We now turn to present and discuss the estimation results.

\section{Empirical Results}

\subsection{The Baseline Specification}

The results from estimating Eq. (19) are presented in table 1. The effect of exchange rate fluctuations on labor compensation in each firm is statistically significant in terms of both the average wage per employee (column 1) and per hour (column 2), and the estimated coefficients of the two interaction terms, capturing the effect of currency swings on wages through, respectively, the foreign sale channel and the imported intermediate inputs channel have the expected sign. If we focus on the response of the (average) wage per employee (Column 1) the estimated coefficient of $\chi_{i t-1} \cdot \Delta$ peer $_{t}$ is -0.722 with a standard error of 0.140 , and the estimated coefficient of $\alpha_{i t-1} \cdot \Delta$ pmer $_{t}$ is 2.608 with a standard error of 0.753. In the case of wage per hour (Column 2) the estimated coefficient of $\chi_{i t-1} \cdot \Delta$ peer $_{t}$ is -0.760 with a standard error of 0.162 , and the estimated coefficient of $\alpha_{i t-1} \cdot \Delta p m e r_{t}$ is 
0.661 with a standard error of 0.336 . These results support the theoretical prediction that a currency depreciation, i.e. a negative variation over time of both peer $_{t}$ and pmer $_{t}$ causes a rise in average real wages through the foreign sales side of the balance sheet and to a decline through the expenditure side. Both effects are estimated to be stronger, respectively, the higher is the firm's international exposure through exports, i.e. the higher is $\chi_{i t-1}$, and the higher is the firm's reliance on imported inputs, i.e. the higher is $\alpha_{i t-1}$.

Naturally, a question arises as to whether an exchange rate appreciation leads to a rise or fall of the labor compensation set by the firm. As argued in NP (2010), our empirical framework is not the most suitable one for ascertaining the aggregate effect of exchange rate swings on wages. On the contrary, the primary advantage of our approach is that it allows to capture the firm-specific relevance of each transmission channel. This implies that a firm-specific, rather than an aggregate, wage response to exchange rates can be estimated on our microeconomic data for each period. To do so, consider first the mean value of both the export share of sales, $\chi_{i t}$, and the share of imported input costs, $\alpha_{i t}$, equal to 0.298 and 0.139 , respectively. If we evaluate the shares reflecting external orientation at these mean values, and use, for example, the estimation results reported in Column 2 of Table 1, the estimated elasticity of wage per hour to exchange rate change is -0.134 . This means that the effect of a one per cent currency depreciation on the hourly wage for a hypothetical firm with this type of foreign exposure is a 0.13 per cent real wage expansion. However, if instead of considering a hypothetical firm exhibiting average shares, we consider firms' heterogeneity in terms of external orientation, by focusing on the difference between import and export shares, $\alpha-\chi$ and in particular on the firms at the 25th, median and 75th percentile of the distribution of this difference, we obtain rather different results. For the firm at the 25th percentile (with $\alpha=0.09$ and $\chi=0.44$ ), based on the results documented in table 1 column 2 , a one per cent currency depreciation determines a 0.27 per cent rise of real wages per hour. For the median firm (with $\alpha=0.12$ and $\chi=0.22$ ), hourly wages rises by 0.09 per cent. For the firm at the 75 th percentile (with $\alpha=0.08$ and $\chi=0.01$ ), hourly wages would drop by 0.05 per cent after a one per cent (export and import) exchange rate depreciation. Figure 2 shows how the estimated effect on wages of a one per cent currency depreciation varies with the export share of sales and with the share of costs of imported inputs on total costs. These results point to a high degree of heterogeneity across firms, suggesting that the analysis of average values may hide substantial recomposition effects within and across industries. 
The estimation results also document that the firm's profit margin as measured by the markup ratio, $M K U P_{i t-1}$, exerts a positive effects on wages, and so does the lagged change in employment (or hours), $\Delta l_{i t-1}$. On the contrary, the change in total sales, included in the specification as a control variable, has no statistically significant effect on wage per employee, while it has a negative and statistically significant effect on wage per hour, possibly owing to the lower hourly cost of overtime employment. As already discussed above, the specification includes a number of dummy variables. We report the value of the Wald tests for the joint significance of each group of dummies, indicating that all these effects are statistically significant. Evidence on the validity of our baseline specification in both columns 1 and 2 is provided by the values of the Hansen statistic for over-identifying restrictions and of the test for absence of second-order serial correlation of residuals.

\subsection{The Role of Market Power}

A notable implication of the theoretical framework of section 2 is that, for a given international exposure, the sensitivity of wages to exchange rate fluctuations is larger for firms with a lower market power in the product markets. We verify empirically this hypothesis estimating our baseline specification on two different sub-samples obtained using the median value of firms' mark-ups as the separating threshold (see CG, 2001 and NP, 2010). The estimation results, reported in table 2, show that the effect of exchange rate swings on (average) labor compensation both per employee and per hour is stronger for firms with a lower mark-up ratio. If we focus, for example, on the impact on compensations per hour, the estimated effect through the cost side is 3.751 with a standard error of 1.204 for the firms with relatively low pricing power, which is indeed larger compared to the corresponding one for firms with higher pricing power (in this case it is 0.528 with a standard error of 0.318 ; see columns 3 and 4 of table 2). By the same token, the estimated impact of exchange rate through the revenue side is -1.182 with a standard error of 0.229 in the case of firms with lower market power, while it is -0.302 (with a standard error of 0.137 ) for firms exhibiting higher pricing power in the product markets. Similar results are obtained considering the impact on wages per employee.

To analyze this issue in more detail we also modify the baseline specification. In particular, we replace the two key explanatory variables in our regression, namely the interac- 
tion terms between exchange rate variations and the variables of firm's international exposure (respectively, $\chi_{i t-1} \cdot \Delta$ peer $_{t}$ and $\alpha_{i t-1} \cdot \Delta$ pmer $_{t}$ ) with two new interaction terms that comprise also the firm's level of market power, i.e. $M K U P_{i t-1}$, as a further multiplicative term. Specifically, the new regressors are (i) $\chi_{i t-1} \cdot \Delta$ peer $_{t} \cdot\left(1-M K U P_{i t-1}\right)$ and (ii) $\alpha_{i t-1} \cdot \Delta \operatorname{pmer}_{t} \cdot\left(1-M K U P_{i t-1}\right)$.

The theoretical model predicts that a depreciation (i.e. a negative value of $\Delta$ peer $_{t}$ ) would increase wages through the revenue side and the impact is expected to be stronger the higher is the share of exports from sale and the lower is the price mark-up. Therefore, a negative estimate of the parameter for the interaction term for the revenue side would lend empirical support to this prediction. Indeed, table 3 shows that the estimated coefficient is -1.100 (with a standard error of 0.184 ) when we consider labor compensation per employee and -0.513 (with a standard error of 0.163 ) when we consider labor compensation per hour. On the other hand, we expect a depreciation to reduce wages through the cost side with the size of the impact being higher (in absolute value) the higher is the share of expenditure on imported input over total costs and the lower is the price mark-up. Estimating a positive parameter for the interaction term on the cost side would support the model's prediction and this is the result we obtain. Indeed, the estimated coefficient is positive and statistically significant when we consider both labor compensation per employee (2.461 with a standard error of 0.848 ; see table 3 , column 1 ) and labor compensation per hour (0.706 with a standard error of 0.342 ; see table 3 , column 2).

\subsection{The Different Degree of Import Penetration}

To further characterize the linkage between exchange rate and wages we analyze some additional features that may contribute to shape the sensitivity of firm level wages to currency shocks.

So far, we have emphasized foreign exposure of a firm as captured by both the extent of the exporting activity and the incidence of imported intermediate inputs. However, the firm is exposed to international competition also in the domestic product markets, and the degree to which this happens depends on (i) the extent of import penetration in the domestic industry to which a firm belongs and (ii) the share of firm's sales in the domestic market over total sales. As we discussed in Section 2, the more relevant are import penetration 
and the firm's exposure to domestic revenues, the more severe is the competitive pressure exerted by foreign producers in the firm's domestic market. This channel introduces another degree of difference across firms in the estimated impact of exchange rate movements on labor compensation. To account for this effect, following NP (2010), we therefore consider the following specification:

$$
\begin{aligned}
& \Delta w_{i t}=\beta_{0}+\beta_{1} \chi_{i t-1} \Delta \text { peer }_{t}+\beta_{2} \alpha_{i t-1} \Delta \text { pmer }_{t}+\beta_{3} \chi_{i t-1}+\beta_{4} \alpha_{i t-1}+ \\
& +\beta_{5} \Delta s_{i t-1}+\beta_{6} M K U P_{i t-1}+\beta_{7} \Delta l_{i t-1}+\sum_{j=1}^{K}\left[\gamma_{j}\left(1-\chi_{i t-1}\right) I P_{j t-1} \Delta p e e r_{t} D_{j}\right]+b^{\prime} Z_{i t}+\lambda_{i}+u_{i t}
\end{aligned}
$$

which is identical to Eq. (19), except for the inclusion of the summation term, that is composed by: (i) $D_{j}$, which is a dummy variable for each industry $j$ (with $j=1,2, \ldots K$ ) and is equal to one if firm $i$ belongs to industry $j$ and zero otherwise; (ii) $I P_{j t-1}$, the (lagged value of the) industry $j$ 's import penetration ratio, as measured by the share of imports of products $j$ over domestic demand for those products, obtained as the industry's sales plus the imports of products of industry $j$ minus the industry's exports; (iii) $\left(1-\chi_{i t-1}\right.$ ), that is the ratio of domestic sales to total sales and reflects the degree of firm's exposure on the domestic product market. All these variables interact with the export exchange rate change, so that for each industry we can estimate an industry-specific coefficient, $\gamma_{j}$, associated with the corresponding interaction term. These coefficients are expected to be negative, because a currency depreciation (a fall of peer $_{t}$ ) augments the firm's competitiveness in the domestic market, thus increasing its profitability through the domestic revenue side and thereby the equilibrium wages. Moreover, the size of this effect will vary across firms depending on the relevance of domestic sales in total sales and on the extent of import penetration. This hypothesis is confirmed by the results from estimating the model in Eq. 20, that are reported in table 4. The coefficients of the two key interaction terms have the expected sign and are statistically significant. In analyzing the industry-specific values of the estimated coefficients $\gamma_{j}$, capturing the effect of exchange rate on wages through import penetration, we first test whether they are different among each others, conducting a Wald test. Indeed, the null hypothesis of identical industry-specific coefficients is strongly rejected (with a p-value of 0.00). In Table 5 we also report the values for each industry $j$ of the estimated wage 
sensitivity to exchange rate through the import penetration channel, that we computed combining the value of the coefficient $\gamma_{j}$ with (i) the corresponding industry-specific average value across firms and over time of $\left(1-\chi_{i t-1}\right)$ and (iii) the time average of $I P_{j t}$ for the industry. In the large majority of industries (12 out of 15$)$ the estimated wage elasticity to exchange rate through the import penetration channel has the expected negative sign. To gauge whether these estimates are sensible, in Table 5 we compare these estimates of the elasticities with the corresponding values of import penetration for each industry that we reported in Table 5, together with the associated rank. As in NP (2010) for the employment elasticity, the estimated impact of exchange rate on wages through the domestic sales side is larger for industries exhibiting a higher degree of import penetration. The strongest effects are recorded for Electrical Machinery and for Computers and Office equipments. For the latter industry, the extent of import penetration is very high (58 per cent; ranked n. 1) and for Electrical Machinery it is also sizeable (29 per cent; ranked n. 4). We have also computed the Spearman's rank correlation between the (absolute values of the) estimated industryspecific wage responses on the domestic sale side and the indexes of import penetration of the corresponding industries. With a value of the Spearman correlation of 0.65 , the null hypothesis that these two variables are independent is rejected at the 1 per cent level of statistical significance. ${ }^{5}$

\footnotetext{
${ }^{5}$ We have also focused in more details on the effects through the cost side, with a possible source of specificity being the different degree of substitutability between imported and domestically produced intermediate inputs. After a depreciation, that increases the price of imported inputs in the domestic currency, a firm may decide to replace its imports of intermediate goods with similar goods that are domestically produced. Arguably, the extent to which this happens may reflect technological and organizational characteristics of the firm, that are shared by the firms in the same industry. If the degree of this substitutability is relatively high (low), then the wage sensitivity to exchange rate through the cost side channel would be relatively low (high). To investigate this issue, we estimate an equation that is identical to Eq. (19), except for the effect of $\alpha_{i t-1} \triangle P M E R_{t}$ on wages that is estimated separately for each industry. To ascertain if the differences between the estimated coefficients summarizing the cost-side effects of exchange rate on wages are significant, we performed a Wald test for the null hypothesis that these differences are equal to zero. The value of the test is 68.7 with a p-value of 0.00 , indicating that differences across industries in the wage sensitivity through the cost side are statistically significant.
} 


\subsection{The Share of Newly Hired Workers and the Composition of the Workforce}

Goldberg and Tracy (2003) point to three different channels of transmission of an exchange rate shock to the worker's wage. In addition to the standard channel of on-the-job wage adjustment in the aftermath of the shock, exchange rate may also influence (i) the likelihood of a job switch and (ii) the size of the revision of the worker's wage conditional to a job transition. Using micro-labor data on individual employees, they document a significant effect of exchange rate on the amount of the worker's wage adjustment associated with a job switch. Kletzer (2000) and Goldberg and Tracy (2003) show that, while a change in, respectively, foreign competition and the currency value account for only a modest share of job displacement, on the other hand job changing does affect the sensitivity of wages to exchange rate (or foreign competition) through the impact of currency swings on the size of the wage adjustment after the job transition.

To address this issue using our firm-level data, we focus on the hiring rate for each firm in a given year and investigate whether firms that are similar in all dimensions (e.g. foreign exposure), except for the percentage of newly hired employees in a given year, do exhibit a different responsiveness of the (average) wage to an exchange rate shock. A relatively large size of the hiring rate in a given year implies that the firm has among its employees a relatively large share of job changers, who have switched job in that year. To appraise this effect on the firm's wage sensitivity to exchange rate, we consider an empirical specification which includes the time-varying firm's hiring rate, hirr $r_{i t}$. Specifically, we augment the two interaction terms between the exchange rate variation and the indicators of the firm's international orientation (respectively, $\chi_{i t-1}$ and $\alpha_{i t-1}$ ) with the hiring rate. The two key regressors therefore become (i) $\chi_{i t-1} \cdot \Delta$ peer $_{t} \cdot \operatorname{hirr}_{i t}$ and (ii) $\alpha_{i t-1} \cdot \Delta P M E R_{t} \cdot h_{i r r}$. Of course, the term hirr $_{i t}$ also enters in isolation in the specification, exactly as $\chi_{i t-1}$ and $\alpha_{i t-1}$ do. The hiring rate is computed as the number of newly hired workers in a given year divided by the total number of employees (the latter is calculated as the simple average between the firm's employment level in periods $t$ and $t-1$; see e.g. Klein, Schuh and Triest, 2003).

Table 6 documents that the wage sensitivity to exchange rate tends to increase with the rate of firm's hires in a given year. Indeed, we estimate that the higher is hirr ${ }_{i t}$ the stronger is the wage responsiveness to the currency shock along both channels of transmission related 
to the exposure of firm profits to international markets (the one through foreign sales and the one through expenditure on imported intermediate inputs). For example, if we focus on the (average) wage per employee, the estimated effect of exchange rate on the export side is negative and statistically significant (-3.875 with a standard error of 1.097) and the one on the imported input side is positive and significant (9.765 with a standard error of 3.495). For an identical degree of foreign exposure, the impact of exchange rate on wages tend therefore to be more pronounced in those firms with a higher proportion of newly hired workers. Interestingly, when taken in isolation, the hiring rate has no statistically significant effect on wages. Although a thorough investigation of this issue would require data at both the firm and individual worker level, we argue that this finding on firm-level data complements the one uncovered by Goldberg and Tracy (2003) on data on individual workers that do not control for the firm's characteristics. ${ }^{6}$

Finally, we focus on the composition of the firm's workforce by occupational group and ask ourselves whether this affects the wage sensitivity to currency swings. We find that it does. In particular, although our data do not provide information on the characteristics of individual employees, we have however information for each firm and in each year on the composition of the firm's workers by type (blue-collar vis-a-vis white-collar). We therefore consider a specification in which we augment the two key interaction terms related to the firm's international exposure with the ratio of white-collars to total workers, whco $i t$ : (i) $\chi_{i t-1} \cdot \Delta$ peer $_{t} \cdot w h c o_{i t}$; and (ii) $\alpha_{i t-1} \cdot \Delta$ pmer $_{t} \cdot w_{h c o}$. The specification also includes the term $w h c o_{i t}$ entering in isolation. In Table 7 we report the results on how the wage responsiveness to exchange rate swings is affected by the composition of the firm workforce by type. The higher is the proportion of white-collar workers in the firm, whco $i t$, the stronger is the wage sensitivity to the exchange rate through the firm exposure to both foreign sales and expenditure for imported intermediate inputs. For example, the estimated effect of an exchange

\footnotetext{
${ }^{6} \mathrm{We}$ also focused on another measure of job flows, namely the job reallocation rate, $j r r_{i t}$, obtained as the sum of the hiring rate defined earlier and the job separation rate (i.e. the ratio between the number of separations in each year, $t$, and the simple average between the firm's employment in periods $t$ and $t-1$ ). When the two key regressors of the baseline specification are augmented as follows: $\chi_{i t-1} \cdot \Delta p e e r_{t} \cdot j r r_{i t}$ and 2) $\alpha_{i t-1} \cdot \Delta$ pmer $_{t} \cdot j r r_{i t}$, the estimation results suggest that a relatively high degree of job turnover in the firm magnifies the effect of exchange rate change on wages through profit adjustment. In particular, the estimated coefficient associated to the first variable is -1.486 with a standard error of 0.420 and the one associated to the second variable is 6.984 with a standard error of 1.838 (the whole set of regression results are not reported for space constraints).
} 
rate appreciation on the (average) wage per employee is negative and statistically significant $(-1.419$ with a standard error of 0.478$)$ through the export side and this implies that, for a given exposure, the higher the proportion of white-collars $\left(w h c o_{i t}\right)$ the stronger is the effect. On the other hand, the estimated effect of an exchange rate appreciation on the wage is positive and statistically significant through the side of expenditure for imported inputs (6.605 with a standard error of 1.298). For a given international exposure, the higher the incidence of white-collar workers, the higher is therefore the effect of exchange rate on wage. The same result is obtained by estimating a simple panel specification in which the estimated firmspecific exchange rate elasticities of wages to exchange rate swings is regressed on the firm's ratio of white-collar employees to total workers (see CG, 2001). In particular, the dependent variable is derived from the results of table 1 (column 1$)$ as $\left(2.608 \cdot \alpha_{i t-1}-0.722 \cdot \chi_{i t-1}\right)$. The regression results indicate that a higher incidence in the firm of the white-collar employees (vis-a-vis the blue-collars) is conducive to a higher estimated wage sensitivity to exchange rate fluctuations. The estimated coefficient is 0.062 with a standard error of 0.014 .

Finally, we also combined the two issues addressed in this section by investigating whether the wage sensitivity to exchange rate shaped by the rate of firm's hires is in turn affected by the composition of the workforce by occupational category. In particular, we split the sample based on the proportion of white-collars in total workers and analyze whether the estimated effects associated to the variables $\chi_{i t-1} \cdot \Delta$ peer $_{t} \cdot h_{i r r}$ and $\alpha_{i t-1} \cdot \Delta p m e r_{t} \cdot h_{i r} r_{i t}$ are different depending on the composition of the workforce. It turns out that it does. In particular, as documented in Table 8, the effects are larger in those firms where the proportion of whitecollar employees is higher than the overall median across firms. If we focus for example on the side of revenues from exporting activities, the estimated coefficient is -2.465 (with a standard error of 0.472 ) for firms with a relatively low proportion of white-collars employee, while it is equal to -4.556 (with a standard error of 0.920 ) for firms where the incidence of white-collars workers is higher.

\section{Concluding Remarks}

Using data on a representative panel of manufacturing firms we find that exchange rate fluctuations do affect the labor compensation set by each firm. Similar to the analysis in NP (2010) on the response of employment and hours conducted on the same microeconomic 
data, we find that the direction and size of wage adjustment is determined by the external orientation of each firm on both the revenue and cost side of its balance sheet. Through the revenue side, a currency depreciation affects firm's profitability and thereby the equilibrium outcome of wages. The latter are shown to rise along this channel and the effect is estimated to be larger the higher is the firm's exposure to revenues from exporting. On the other hand, a depreciation leads to a reduction of the firm's wages through the channel of expenditure for imported inputs and the effect is larger the higher is the firm's reliance on imported vis-a-vis domestically produced inputs. Our results indicate that, for a given type of firm's international exposure, the responsiveness of wages to exchange rate is more pronounced for firms with a lower degree of pricing power.

To provide further characterizations of the wage sensitivity, we also document that other transmission channels introduce a significant source of heterogeneity across firms in the response of wages to exchange rate swings. These include the extent of competition in the domestic marked exerted by foreign producers, as measured by the import penetration in the domestic industry to which a firm belongs. We also analyze the percentage of newly hired workers of a firm in a given year and document that a larger presence in the firm of job changers affects the size of wage adjustment in response to exchange rate variations. Finally, we find that the composition of the firm's workforce by occupational category does influence the sensitivity of wages to exchange rate, with the latter being higher, ceteris paribus, when the incidence in the firm of white-collar employees is relatively large.

Overall, our results highlight a further channel through which currency oscillations can have significant effects on the real economy. Most important, these effects show wide differences, even in their sign, depending on individual firm's characteristics. Beyond average effects, currency oscillations can therefore have substantial redistributive effects within and across industries.

\section{Acknowledgements}

This project was begun while Alberto Pozzolo was with the Research Department of the Bank of Italy. We thank Linda Goldberg, Paolo Naticchioni and seminar participants at the IEA Conference in Beijing, the University of Trento and the XIX Tor Vergata University Conference on Money, Banking and Finance (Rome) for useful discussions. E-mail addresses: francesco.nucci@uniroma1.it; pozzolo@unimol.it. 


\section{References}

[1] Abowd, J.A. and Lemieux, T., (1993), "The effects of product market competition on collective bargaining agreements: The case of foreign competition in Canada", Quarterly Journal of Economics, 983-1014.

[2] Arai, M., (2003), "Wages, Profits, and Capital Intensity: Evidence from Matched Worker-Firm Data", Journal of Labor Economics, vol. 21, no. 3, 593-618.

[3] Arellano, M. and S. R. Bond (1991), "Some Tests of Specification for Panel Data: Monte Carlo Evidence and an Application to Employment Equations", Review of Economic Studies, 58, 277-297.

[4] Arellano, M. and O. Bover (1995), "Another Look at the Instrumental Variable Estimation of Error-components Models", Journal of Econometrics, 68, 29-51.

[5] Banca d'Italia (1998), "Nuovi Indicatori di Tasso di Cambio Effettivo Nominale e Reale", Bollettino Economico 30, 1*-8*.

[6] Bernard, A.B., J.B. Jensen, S.J. Redding and P.K. Schott (2007), "Firms In International Trade", Journal of Economic Perspectives, 21, 105-130.

[7] Beveridge, S. and C. R. Nelson (1981), "New Approach to Decomposition of Economic Time Series into Permanent and Transitory Components with Particular Attention to Measurement of the 'Business Cycle"', Journal of Monetary Economics, 7, 151-174.

[8] Blanchfiower, D.G., Oswald, A.J., and Sanfey, P. (1996), "Wages, Profits, and RentSharing", Quarterly Journal of Economics, 111, 227-52

[9] Campa, J. and L. Goldberg, (1999), "Investment, Pass-Through and Exchange Rates: a Cross-Country Comparison", International Economic Review, 40, 287-314.

[10] Campa, J. and Goldberg, L. (2001), "Employment versus Wage Adjustment and the U.S. Dollar", Review of Economics and Statistics, 83, 477-489.

[11] Domowitz, I., R. G. Hubbard and C. Petersen, (1986), "Business Cycles and the Relationship between Concentration and Profit Margins", Rand Journal of Economics 17, $1-17$. 
[12] Dornbusch, R. (1987), "Exchange Rates and Prices", American Economic Review, 77, 93-106.

[13] Goldberg, L. and J. Tracy (2000), "Exchange Rates and Local Labor Markets", in R. Feenstra (ed.), The Impact of International Trade on Wages, NBER and University of Chicago Press.

[14] Goldberg, L. and J. Tracy (2003), "Exchange Rates and Wages", Revised version of the NBER working paper n. 8137, 2001.

[15] Hildreth, A.K.G., and Oswald, A.J. (1997), "Rent-Sharing and Wages: Evidence from Company and Establishment Panels" Journal of Labor Economics, 15, 318-37

[16] Klein, M.W., S. Schuh, R.K., Triest, (2003), "Job Creation, Job Destruction, and the Real Exchange Rate", Journal of International Economics, Vol. 59, 2, 239-265.

[17] Kletzer, L. (2000), "Trade and Job Loss in U.S. Manufacturing, 1979-94", in R. Feenstra (ed.), The Impact of International Trade on Wages, NBER and University of Chicago Press.

[18] Knetter, M. (1993), "International Comparisons of Pricing-to Market Behavior", American Economic Review, 83, 473-486.

[19] Nickell, S. and S. Wadhwani, (1990), "Insider Forces and Wage Determination", Economic Journal, C, 496-509.

[20] Nucci, F. and A.F. Pozzolo (2001), "Investment and the Exchange Rate: an Analysis with Firm-Level Panel Data", European Economic Review, 45, 259-283.

[21] Nucci, F. and A.F. Pozzolo (2010), Exchange rate, Employment and Hours: what Firmlevel Data Say", Journal of International Economics, 82, 112123.

[22] Revenga, A. (1992), "Exporting Jobs? The Impact of Import Competition on mployment and Wages in U.S. Manufacturing", Quarterly Journal of Economics, 94, S111-143.

[23] Yang, J., (1997), "Exchange Rate Pass-through in U.S. Manufacturing Industries", Review of Economics and Statistics, 79, 95-104. 
Figure 1

Real import and export exchange rates $(1998=100)$

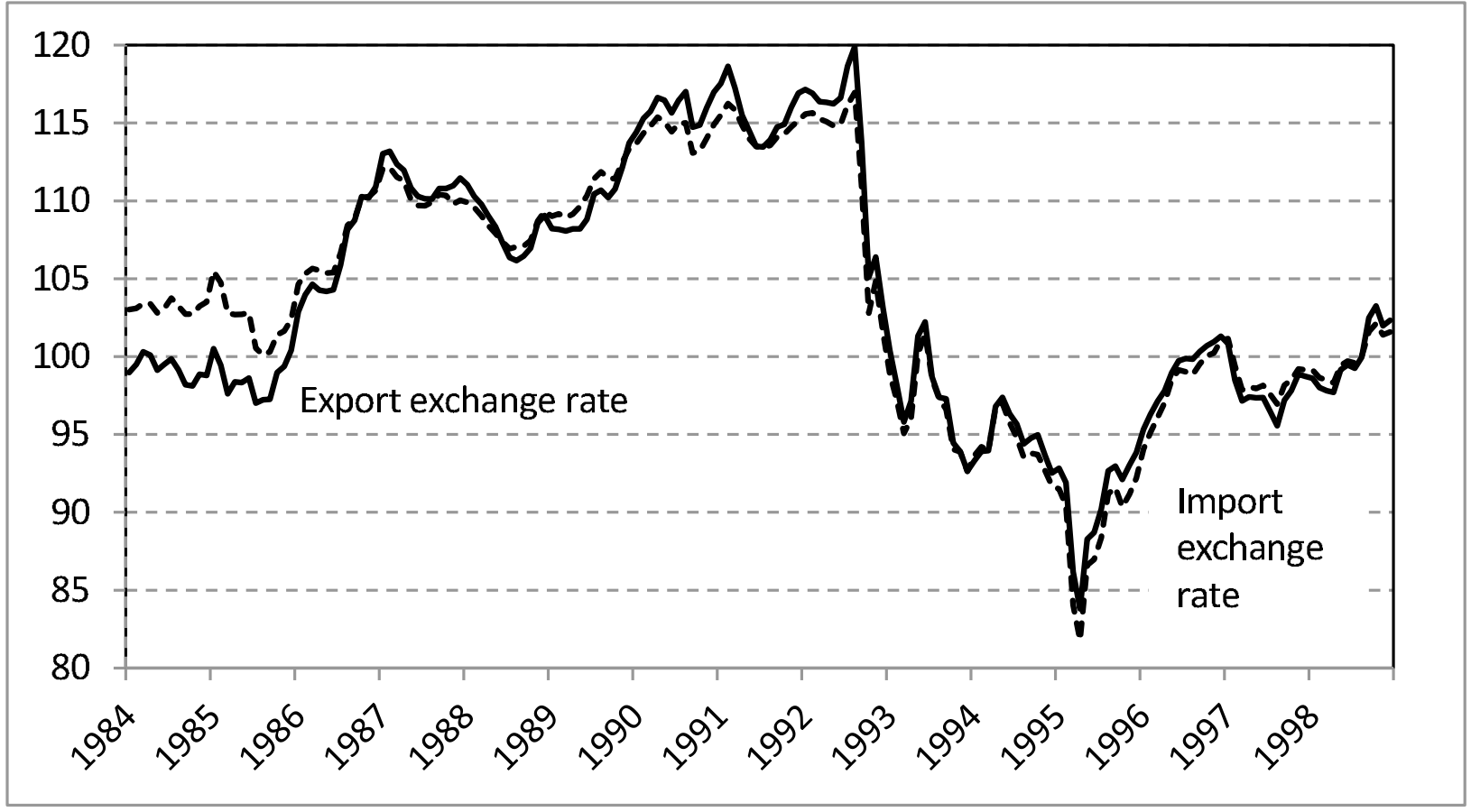

Source: Bank of Italy. 
Figure 2

The heterogeneous impact of a one per cent depreciation on wages depending on the external orientation of firms

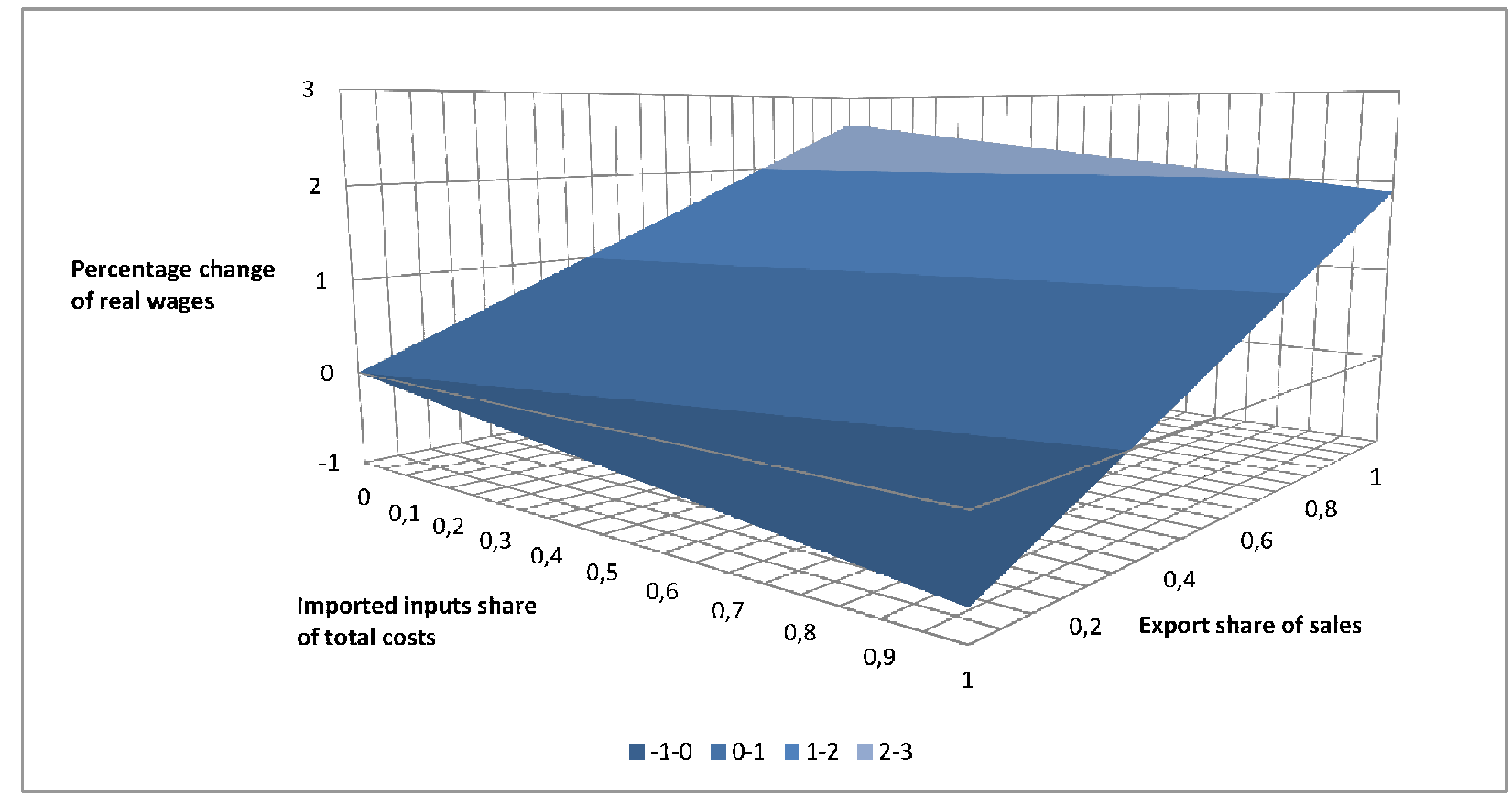


Table 1

The Effect of Exchange Rate Change on Wages

\begin{tabular}{|c|c|c|}
\hline \multirow[b]{2}{*}{ Variable } & $(1)$ & $(2)$ \\
\hline & $\begin{array}{l}\text { Labor compensation } \\
\text { per employee: } \Delta w_{i t}\end{array}$ & $\begin{array}{l}\text { Labor compensation } \\
\text { per hour: } \Delta w h_{i t}\end{array}$ \\
\hline \multirow[t]{2}{*}{$\alpha_{i t-1} \cdot \Delta p m e r_{t}$} & $2.608^{* *}$ & $0.661^{* *}$ \\
\hline & $(0.753)$ & $(0.336)$ \\
\hline \multirow[t]{2}{*}{$\chi_{i t-1} \cdot \Delta p e e r_{t}$} & $-0.722^{* *}$ & $-0.760^{* *}$ \\
\hline & $(0.140)$ & $(0.162)$ \\
\hline \multirow[t]{2}{*}{$\alpha_{i t-1}$} & $0.251^{* *}$ & $0.263^{* *}$ \\
\hline & $(0.036)$ & $(0.047)$ \\
\hline \multirow[t]{2}{*}{$\chi_{i t-1}$} & -0.004 & -0.003 \\
\hline & $(0.003)$ & 0.004 \\
\hline \multirow[t]{2}{*}{$M K U P_{i t-1}$} & $0.126^{* *}$ & $0.053^{* *}$ \\
\hline & $(0.013)$ & $(0.016)$ \\
\hline \multirow[t]{2}{*}{$\Delta s_{i t-1}$} & 0.001 & $-0.011^{* *}$ \\
\hline & $(0.003)$ & $(0.004)$ \\
\hline \multirow[t]{2}{*}{$\Delta l_{i t-1}$} & $0.046^{* *}$ & $0.069^{* *}$ \\
\hline & $(0.009)$ & $(0.012)$ \\
\hline \multirow[t]{2}{*}{ Constant } & $-0.045^{* *}$ & -0.018 \\
\hline & $(0.010)$ & $(0.012)$ \\
\hline Year dummies & $809.4(0.0)$ & $192.1(0.0)$ \\
\hline Industry dummies & $168.9(0.0)$ & $117.6(0.0)$ \\
\hline Geography dummies & $10.0(0.0)$ & $3.8(0.4)$ \\
\hline Firm size dummies & $12.7(0.0)$ & $26.5(0.0)$ \\
\hline Hansen test of over-identifying restrictions: & $283.5(0.13)$ & $276.8(0.20)$ \\
\hline Test for second-order serial correlation & $1.26(0.21)$ & $0.81(0.42)$ \\
\hline Number of observations & 6,580 & 6,447 \\
\hline
\end{tabular}

Notes: The system GMM dynamic panel methodology is used for estimation. $\alpha_{i t-1}$ is the share of expenditure for imported inputs and $\chi_{i t-1}$ is the export share of sales. $\Delta p m e r_{t}$ and $\Delta p e e r_{t}$ are the (log) changes in the permanent component of, respectively, the import and export exchange rate. $\Delta \mathrm{s}_{i t-1}$ is the $(\log )$ variation of real sales and $M K U P_{i t-1}$ is the firm's mark-up ratio. $\Delta \mathrm{l}_{i t-1}$ is the (log) variation of labor input and is measured as number of employees in column 1 and as number of hours in column 2. Size dummies refer to these sizes: 50-99, 100-199, 200-499, 500-999, $\geq 1000$ employees. Geographic dummies refer to NorthWest, North-East, Center, South, Islands. For each group of dummies we report the value of Wald test of their joint significance and the associated p-value. Standard errors are corrected for heteroskedasticity and reported in parentheses. The instrument set includes lagged values of changes of labor inputs, sales and the mark-up dated t-2 and earlier. Hansen is a test of over-identifying restrictions asymptotically distributed as a $\chi^{2}$. We also report the value of the test for second-order autocorrelation of the differenced residuals (the p-values are reported in parenthes). Sample period: 1984-1998. ${ }^{* *}$ denotes significance at the $5 \%$ confidence level and ${ }^{*}$ at the $10 \%$. 
Table 2

Exchange rate, Market Power and Wage Adjustment (I)

\begin{tabular}{|c|c|c|c|c|}
\hline \multirow{3}{*}{ Variable } & $(1)$ & $(2)$ & $(3)$ & $(4)$ \\
\hline & \multicolumn{2}{|c|}{$\begin{array}{c}\text { Compensation per employee: } \Delta w_{i t} \\
\text { Degree of market power }\end{array}$} & \multicolumn{2}{|c|}{$\begin{array}{c}\text { Compensation per hour: } \Delta w h_{i t} \\
\text { Degree of market power }\end{array}$} \\
\hline & Low & High & Low & High \\
\hline \multirow[t]{2}{*}{$\alpha_{i t-1} \cdot \Delta p m e r_{t}$} & $2.848^{* *}$ & $2.743^{* *}$ & $3.751^{* *}$ & $0.528^{* *}$ \\
\hline & $(0.819)$ & $(0.891)$ & $(1.204)$ & $(0.318)$ \\
\hline \multirow[t]{2}{*}{$\chi_{i t-1} \cdot \Delta$ peer $_{t}$} & $-1.281^{* *}$ & $-0.375^{* *}$ & $-1.182^{* *}$ & $-0.302^{* *}$ \\
\hline & $(0.163)$ & $(0.170)$ & $(0.229)$ & $(0.137)$ \\
\hline \multirow[t]{2}{*}{$\alpha_{i t-1}$} & $0.368^{* *}$ & $0.215^{* *}$ & $0.366^{* *}$ & $0.285^{* *}$ \\
\hline & $(0.055)$ & $(0.049)$ & $(0.068)$ & $(0.048)$ \\
\hline \multirow[t]{2}{*}{$\chi_{i t-1}$} & -0.007 & -0.001 & -0.007 & 0.001 \\
\hline & $(0.005)$ & $(0.004)$ & $(0.006)$ & $(0.005)$ \\
\hline \multirow[t]{2}{*}{$\Delta s_{i t-1}$} & $0.016^{* *}$ & $-0.016^{* *}$ & $-0.006^{* *}$ & $-0.018^{* *}$ \\
\hline & $(0.003)$ & $(0.004)$ & $(0.003)$ & $(0.003)$ \\
\hline \multirow[t]{2}{*}{$M K U P_{i t-1}$} & $0.127^{* *}$ & $0.168^{* *}$ & $0.114^{* *}$ & $0.194^{* *}$ \\
\hline & $(0.012)$ & $(0.034)$ & $(0.015)$ & $(0.027)$ \\
\hline \multirow[t]{2}{*}{$\Delta l_{i t-1}$} & $0.083^{* *}$ & -0.015 & $0.147^{* *}$ & 0.072 \\
\hline & $(0.010)$ & $(0.014)$ & $(0.009)$ & $(0.009)$ \\
\hline \multirow[t]{2}{*}{ Constant } & $-0.053^{* *}$ & $-0.051^{* *}$ & -0.006 & $-0.058^{* *}$ \\
\hline & $(0.013)$ & $(0.015)$ & $(0.019)$ & $(0.015)$ \\
\hline Year dummies & $430.2(0.0)$ & $489.3(0.0)$ & $121.0(0.0)$ & $210.3(0.0)$ \\
\hline Industry dummies & $76.2(0.0)$ & $85.1(0.0)$ & $36.5(0.0)$ & $137.3(0.0)$ \\
\hline Geography dummies & $14.0(0.0)$ & $15.7(0.0)$ & $15.2(0.0)$ & $18.9(0.0)$ \\
\hline Firm size dummies & $6.8(0.2)$ & $10.0(0.0)$ & $12.5(0.0)$ & $24.4(0.0)$ \\
\hline \multicolumn{5}{|l|}{ Hansen test of } \\
\hline over-identifying restrictions & $260.9(0.16)$ & $210.5(0.09)$ & $248.8(0.17)$ & $275.5(0.22)$ \\
\hline \multicolumn{5}{|l|}{ Test for second-order } \\
\hline serial correlation & $1.18(0.24)$ & $1.82(0.07)$ & $0.60(0.55)$ & $-0.54(0.59)$ \\
\hline Number of observations & 3,335 & 3,245 & 3,123 & 3,212 \\
\hline
\end{tabular}

Notes: see Table 1. The system GMM dynamic panel methodology is used for estimation. The sample is split based on the degree of firms'market power. The threshold criterion is the median of firms'mark-up. Variables in lower-case letters denote their logarithmic transformation. ${ }^{* *}$ denotes significance at the $5 \%$ confidence level and ${ }^{*}$ at the $10 \%$ level. 
Table 3

Exchange rate, Market Power and Wage Adjustment (II)

\begin{tabular}{lcc}
\hline \hline \multicolumn{1}{c}{ Variable } & \multicolumn{2}{c}{ Real Wages: $\Delta w_{i t}$} \\
\hline & $(1)$ & $(2)$ \\
& Labor compensation & Labor compensation \\
& per employee: $\Delta w_{i t}$ & per hour: $\Delta w h_{i t}$ \\
$\alpha_{i t-1} \cdot \Delta p m e r_{t} \cdot\left(1-M K U P_{i t-1}\right)$ & $2.461^{* *}$ & $0.706^{* *}$ \\
& $(0.848)$ & $(0.342)$ \\
$\chi_{i t-1} \cdot \Delta p e e r_{t} \cdot\left(1-M K U P_{i t-1}\right)$ & $-1.100^{* *}$ & $-0.513^{* *}$ \\
& $(0.184)$ & $(0.163)$ \\
$\alpha_{i t-1}$ & $0.248^{* *}$ & $0.244^{* *}$ \\
& $(0.040)$ & $(0.044)$ \\
$\chi_{i t-1}$ & -0.005 & 0.001 \\
& $(0.004)$ & $(0.004)$ \\
$\Delta s_{i t-1}$ & -0.001 & -0.003 \\
& $(0.004)$ & $(0.004)$ \\
$M K U P_{i t-1}$ & $0.141^{* *}$ & $0.052^{* *}$ \\
$\Delta l_{i t-1}$ & $(0.016)$ & $(0.015)$ \\
Constant & $0.048^{* *}$ & 0.083 \\
& $(0.011)$ & $(0.012)$ \\
Year dummies & $-0.048^{* *}$ & -0.014 \\
Industry dummies & $(0.010)$ & $(0.011)$ \\
Geography dummies & $576.2(0.00)$ & $187.0(0.00)$ \\
Firm size dummies & $142.0(0.00)$ & $62.3(0.00)$ \\
\hline Hansen test of over-identifying restrictions: & $11.2(0.02)$ & $3.7(0.45)$ \\
Test for second-order serial correlation & $9.9(0.04)$ & $20.6(0.00)$ \\
Number of observations & $229.3(0.09)$ & $275.1(0.22)$ \\
\hline \hline
\end{tabular}

Notes: see Table 1. The system GMM dynamic panel methodology is used for estimation. Variables in lower-case letters denote their logarithmic transformation. ${ }^{* *}$ denotes significance at the $5 \%$ confidence level and ${ }^{*}$ at the $10 \%$ level. 
Table 4

Exchange Rate, Import Penetration and Wage Adjustment

\begin{tabular}{|c|c|}
\hline Variable & $\begin{array}{l}\text { Labor compensation } \\
\text { per employee: } \Delta w_{i t}\end{array}$ \\
\hline \multirow[t]{2}{*}{$\alpha_{i t-1} \cdot \Delta p m e r_{t}$} & $5.809^{* *}$ \\
\hline & $(2.482)$ \\
\hline \multirow[t]{2}{*}{$\chi_{i t-1} \cdot \Delta$ peer $_{t}$} & $-2.130^{* *}$ \\
\hline & $(1.0841)$ \\
\hline \multirow{2}{*}{$\begin{array}{r}\left(1-\chi_{i t-1}\right) \cdot \Delta \text { peer }_{t} \cdot I P_{1 t-1} \cdot D_{1}, \quad\left(1-\chi_{i t-1}\right) \cdot \Delta \text { peer }_{t} \cdot I P_{2 t-1} \cdot D_{2}, \ldots \\
\ldots,\left(1-\chi_{i t-1}\right) \cdot \Delta \text { peer }_{t} \cdot I P_{K t-1} \cdot D_{K}\end{array}$} & Wald test: \\
\hline & 40.3 ( $p$-val: 0.00$)$ \\
\hline \multirow{2}{*}{$\alpha_{i t-1}$} & $0.120^{*}$ \\
\hline & $(0.063)$ \\
\hline \multirow[t]{2}{*}{$\chi_{i t-1}$} & $-0.009^{*}$ \\
\hline & $(0.005)$ \\
\hline \multirow[t]{2}{*}{$\Delta s_{i t-1}$} & -0.001 \\
\hline & $(0.004)$ \\
\hline \multirow[t]{2}{*}{$M K U P_{i t-1}$} & $0.033^{* *}$ \\
\hline & $(0.014)$ \\
\hline \multirow[t]{2}{*}{$\Delta l_{i t-1}$} & -0.017 \\
\hline & $(0.016)$ \\
\hline \multirow[t]{2}{*}{ Constant } & -0.009 \\
\hline & $(0.031)$ \\
\hline Year dummies & $219.0(0.00)$ \\
\hline Industry dummies & $52.8(0.00)$ \\
\hline Geography dummies & $11.9(0.02)$ \\
\hline Firm size dummies & $5.2(0.27)$ \\
\hline Hansen test of over-identifying restrictions: & $175.2(0.40)$ \\
\hline Test for second-order serial correlation & $1.50(0.13)$ \\
\hline Number of observations & 5,183 \\
\hline
\end{tabular}

Notes: see Table 1. The system GMM dynamic panel methodology is used for estimation. IP $\mathrm{I}_{j t}$ is the value of import penetration experienced by industry $j$ (to which firm i belongs) in the year $t$. $\mathrm{D}_{j}$ is the $j$-th industry dummy, taking the value of one if firm $i$ belongs to industry $j$ and zero otherwise. The Wald statistic associated with the variables $\left(1-\chi_{i t-1}\right) \cdot \Delta$ peer $_{t} \cdot I P_{j t-1} \cdot D_{j}(j=1,2, \ldots, K)$ tests for the joint hypothesis that their coefficients are equal. Variables in lower-case letters denote their logarithmic transformation. ${ }^{* *}$ denotes significance at the $5 \%$ confidence level and * at the $10 \%$ level. 
Table 5

Import Penetration across Industries and the Sensitivity of Wage to Exchange Rate

\begin{tabular}{lcccc}
\hline \multirow{2}{*}{\multicolumn{1}{c}{ Industry }} & \multicolumn{2}{c|}{$\begin{array}{c}\text { Import } \\
\text { penetration }\end{array}$} & \multicolumn{2}{c}{$\begin{array}{c}\text { Wage Response through } \\
\text { import penetration }\end{array}$} \\
\cline { 2 - 5 } Transformation of non metalliferous minerals & 0.10 & 14 & 0.77 & 13 \\
\cline { 2 - 5 } Chemicals & 0.35 & 3 & -1.08 & 6 \\
Metals & 0.05 & 15 & -1.00 & 7 \\
Machinery for industry and agriculture & 0.25 & 5 & -0.61 & 9 \\
Computers, office equipments, precision instruments & 0.58 & 1 & -1.67 & 2 \\
Electrical machinery & 0.29 & 4 & -2.21 & 1 \\
Motor-cars and other transport equipments & 0.54 & 2 & -1.46 & 3 \\
Food and tobacco products & 0.16 & 7 & -1.19 & 5 \\
Textiles & 0.16 & 8 & -0.49 & 11 \\
Leather and footwear & 0.17 & 6 & -1.19 & 4 \\
Clothing & 0.14 & 12 & -0.56 & 10 \\
Wood and furniture & 0.15 & 11 & -0.13 & 12 \\
Paper and publishing & 0.12 & 13 & -0.73 & 8 \\
Rubber and plastic products & 0.15 & 9 & 0.97 & 14 \\
Other manufactures & 0.15 & 10 & 1.39 & 15 \\
\hline \hline
\end{tabular}

Notes: To derive import penetration for each industry and the industry-specific estimated response of wages to exchange rate through import penetration see the discussion in the text. The industry-specific wage responses are obtained from the estimation results documented in Table 4; the ranks of these estimated effects pertains to their absolute values. 
Table 6

Exchange rate, Newly Hired Workers and Wage Adjustment

\begin{tabular}{|c|c|c|}
\hline \multirow[t]{2}{*}{ Variable } & \multicolumn{2}{|c|}{ Real Wages: $\Delta w_{i t}$} \\
\hline & $(1)$ & $(2)$ \\
\hline \multirow{4}{*}{$\alpha_{i t-1} \cdot \Delta \operatorname{pmer}_{t} \cdot$ hirr $_{i t}$} & Labor compensation & Labor compensation \\
\hline & per employee: $\Delta w_{i t}$ & per hour: $\Delta w h_{i t}$ \\
\hline & $9.765^{* *}$ & $8.246^{* *}$ \\
\hline & $(3.495)$ & $(3.416)$ \\
\hline \multirow[t]{2}{*}{$\chi_{i t-1} \cdot \Delta$ peer $_{t} \cdot$ hirr $_{i t}$} & $-3.875^{* *}$ & $-4.508^{* *}$ \\
\hline & $(1.097)$ & $(1.391)$ \\
\hline \multirow[t]{2}{*}{ hirr $_{i t}$} & -0.007 & -0.020 \\
\hline & $(0.007)$ & $(0.007)$ \\
\hline \multirow[t]{2}{*}{$\alpha_{i t-1}$} & $0.254^{* *}$ & $0.247^{* *}$ \\
\hline & $(0.037)$ & $(0.047)$ \\
\hline \multirow[t]{2}{*}{$\chi_{i t-1}$} & -0.002 & -0.001 \\
\hline & $(0.003)$ & $(0.004)$ \\
\hline \multirow[t]{2}{*}{$\Delta s_{i t-1}$} & 0.001 & $-0.008^{* *}$ \\
\hline & $(0.003)$ & $(0.004)$ \\
\hline \multirow[t]{2}{*}{$m k u p_{i t-1}$} & $0.121^{* *}$ & $0.051^{* *}$ \\
\hline & $(0.013)$ & $(0.016)$ \\
\hline \multirow[t]{2}{*}{$\Delta l_{i t-1}$} & $0.043^{* *}$ & $0.065^{* *}$ \\
\hline & $(0.001)$ & $(0.013)$ \\
\hline \multirow[t]{2}{*}{ Constant } & $-0.045^{* *}$ & -0.010 \\
\hline & $(0.010)$ & $(0.012)$ \\
\hline Year dummies & $807.2(0.00)$ & $195.2(0.00)$ \\
\hline Industry dummies & $190.7(0.00)$ & $116.9(0.00)$ \\
\hline Geography dummies & $7.1(0.13)$ & $3.5(0.47)$ \\
\hline Firm size dummies & $9.7(0.05)$ & $25.0(0.00)$ \\
\hline Hansen test of over-identifying restrictions: & $279.9(0.17)$ & $275.6(0.22)$ \\
\hline Test for second-order serial correlation & $1.20(0.23)$ & $0.82(0.41)$ \\
\hline Number of observations & 6,580 & 6,447 \\
\hline
\end{tabular}

Notes: see Table 1. The system GMM dynamic panel methodology is used for estimation. Variables in lower-case letters denote their logarithmic transformation. hirr ${ }_{i t}$ is the hiring rate as defined in the text. ${ }^{* *}$ denotes significance at the $5 \%$ confidence level and * at the $10 \%$ level. 
Table 7

Exchange rate, the Composition of the Workforce by Type and Wage Adjustment

\begin{tabular}{|c|c|c|}
\hline \multirow[t]{2}{*}{ Variable } & \multicolumn{2}{|c|}{ Real Wages: $\Delta w_{i t}$} \\
\hline & $(1)$ & $(2)$ \\
\hline & Labor compensation & Labor compensation \\
\hline \multirow{3}{*}{$\alpha_{i t-1} \cdot \Delta$ pmer $_{t} \cdot w h c o_{i t}$} & per employee: $\Delta w_{i t}$ & per hour: $\Delta w h_{i t}$ \\
\hline & $6.605^{* *}$ & $2.501^{* *}$ \\
\hline & $(1.298)$ & $(0.669)$ \\
\hline \multirow[t]{2}{*}{$\chi_{i t-1} \cdot \Delta$ peer $_{t} \cdot w_{h c o}{ }_{i t}$} & $-1.419^{* *}$ & $-0.994^{* *}$ \\
\hline & $(0.478)$ & $(0.496)$ \\
\hline \multirow[t]{2}{*}{$w h c o_{i t}$} & $0.019^{* *}$ & -0.001 \\
\hline & $(0.006)$ & $(0.007)$ \\
\hline \multirow[t]{2}{*}{$\alpha_{i t-1}$} & $0.228^{* *}$ & $0.229^{* *}$ \\
\hline & $(0.039)$ & $(0.048)$ \\
\hline \multirow[t]{2}{*}{$\chi_{i t-1}$} & -0.002 & -0.003 \\
\hline & $(0.003)$ & $(0.004)$ \\
\hline \multirow[t]{2}{*}{$\Delta s_{i t-1}$} & -0.001 & $-0.009^{* *}$ \\
\hline & $(0.003)$ & $(0.004)$ \\
\hline \multirow[t]{2}{*}{$m k u p_{i t-1}$} & $0.137^{* *}$ & $0.051^{* *}$ \\
\hline & $(0.015)$ & $(0.017)$ \\
\hline \multirow[t]{2}{*}{$\Delta n_{i t-1}$} & $0.041^{* *}$ & $0.067^{* *}$ \\
\hline & $(0.010)$ & $(0.013)$ \\
\hline \multirow[t]{2}{*}{ Constant } & $-0.047^{* *}$ & -0.010 \\
\hline & $(0.010)$ & $(0.012)$ \\
\hline Year dummies & $681.4(0.00)$ & $181.9(0.00)$ \\
\hline Industry dummies & $166.3(0.00)$ & $95.3(0.00)$ \\
\hline Geography dummies & $11.4(0.02)$ & $5.1(0.27)$ \\
\hline Firm size dummies & $15.4(0.00)$ & $21.8(0.00)$ \\
\hline Hansen test of over-identifying restrictions: & $254.7(0.15)$ & $258.6(0.11)$ \\
\hline Test for second-order serial correlation & $1.20(0.23)$ & $0.76(0.45)$ \\
\hline Number of observations & 6,580 & 6,447 \\
\hline
\end{tabular}

Notes: see Table 1. The system GMM dynamic panel methodology is used for estimation. Variables in lowercase letters denote their logarithmic transformation. $w h c_{i t}$ is the proportion of white-collar employees in total workers. ${ }^{* *}$ denotes significance at the $5 \%$ confidence level and ${ }^{*}$ at the $10 \%$ level. 
Table 8

Exchange rate, Firm's Hires and the Composition of the Workforce

\begin{tabular}{|c|c|c|}
\hline \multirow[t]{3}{*}{ Variable } & \multicolumn{2}{|c|}{ Real Wages per employee: $\Delta w_{i t}$} \\
\hline & $(1)$ & $(2)$ \\
\hline & $\begin{array}{l}\text { Firms with a higher proportion } \\
\text { of white-collars (High } w h c o_{i t} \text { ) }\end{array}$ & $\begin{array}{l}\text { Firms with a lower proportion } \\
\text { of white-collars (Low } w h c o_{i t} \text { ) }\end{array}$ \\
\hline \multirow[t]{2}{*}{$\alpha_{i t-1} \cdot \Delta$ pmer $_{t} \cdot$ hirr $_{i t}$} & $11.915^{* *}$ & $6.560^{* *}$ \\
\hline & $(2.218)$ & $(1.912)$ \\
\hline \multirow[t]{2}{*}{$\chi_{i t-1} \cdot \Delta$ peer $_{t} \cdot \operatorname{hirr}_{i t}$} & $-4.556^{* *}$ & $-2.465^{* *}$ \\
\hline & $(0.920)$ & $(0.472)$ \\
\hline \multirow[t]{2}{*}{ hirr $_{i t}$} & $0.020^{* *}$ & -0.002 \\
\hline & $(0.007)$ & $(0.004)$ \\
\hline \multirow{2}{*}{$\alpha_{i t-1}$} & $0.520^{* *}$ & $0.105^{* *}$ \\
\hline & $(0.050)$ & $(0.037)$ \\
\hline \multirow[t]{2}{*}{$\chi_{i t-1}$} & $0.014^{* *}$ & -0.002 \\
\hline & $(0.004)$ & $(0.003)$ \\
\hline \multirow[t]{2}{*}{$\Delta s_{i t-1}$} & $0.009^{* *}$ & $-0.018^{* *}$ \\
\hline & $(0.002)$ & $(0.005)$ \\
\hline \multirow[t]{2}{*}{$m k u p_{i t-1}$} & $0.095^{* *}$ & $0.067^{* *}$ \\
\hline & $(0.011)$ & $(0.013)$ \\
\hline \multirow[t]{2}{*}{$\Delta n_{i t-1}$} & $0.073^{* *}$ & $0.014^{*}$ \\
\hline & $(0.008)$ & $(0.009)$ \\
\hline \multirow[t]{2}{*}{ Constant } & $-0.090^{* *}$ & -0.029 \\
\hline & $(0.015)$ & $(0.009)$ \\
\hline Year dummies & $824.6(0.00)$ & $758.4(0.00)$ \\
\hline Industry dummies & $222.6(0.00)$ & $64.4(0.00)$ \\
\hline Geography dummies & $14.5(0.01)$ & $30.5(0.47)$ \\
\hline Firm size dummies & $31.4(0.00)$ & $21.7(0.00)$ \\
\hline Hansen test of over-identifying restrictions: & $288.1(0.10)$ & $250.7(0.62)$ \\
\hline Test for second-order serial correlation & $1.12(0.26)$ & $1.53(0.13)$ \\
\hline Number of observations & 3,265 & 3,315 \\
\hline
\end{tabular}

Notes: see Table 1. The system GMM dynamic panel methodology is used for estimation. Variables in lower-case letters denote their logarithmic transformation. hirr ${ }_{i t}$ is the hiring rate as defined in the text and $w h c_{i t}$ is the proportion of white-collar employees in total workers. ${ }^{* *}$ denotes significance at the $5 \%$ confidence level and * at the $10 \%$ level. 